\title{
Assessment of Lactational Performance in Dairy Cows Receiving a Rumen Protected B Vitamin Blend during Lactation: Part 2: A Regression Analysis of 50 Studies
}

\author{
Essi Evans ${ }^{1 *}$, Helene Leclerc ${ }^{2}$, Emilie Fontaine ${ }^{2}$, Ousama Al Zahal ${ }^{3}$, Elizabeth Santin ${ }^{2}$ \\ ${ }^{1} \mathrm{E}+\mathrm{E}$ Technical Advisory Services, Bowmanville, Ontario, Canada \\ ${ }^{2}$ Jefo Nutrition, Inc., St. Hyacinthe, Quebec, Canada \\ ${ }^{3} \mathrm{AlZahal}$ Innovation and Nutrition, Kitchener, Ontario, Canada \\ Email: *essievans@sympatico.ca
}

How to cite this paper: Evans, E., Leclerc, H., Fontaine, E., Al Zahal, O. and Santin, E. (2021) Assessment of Lactational Performance in Dairy Cows Receiving a Rumen Protected B Vitamin Blend during Lactation: Part 2: A Regression Analysis of 50 Studies. Open Journal of Animal Sciences, 11, 623-634.

https://doi.org/10.4236/ojas.2021.114042

Received: August 11, 2021

Accepted: September 27, 2021

Published: September 30, 2021

Copyright $\odot 2021$ by author(s) and Scientific Research Publishing Inc. This work is licensed under the Creative Commons Attribution International License (CC BY 4.0).

http://creativecommons.org/licenses/by/4.0/ (c) (i) Open Access

\begin{abstract}
A previous series of meta-analyses demonstrated that a protected blend of $B$ vitamins (RPBV: folic acid, B12, pyridoxine, pantothenic acid, and biotin; Jefo, St. Hyacinthe, QC, Canada) improved milk fat and protein yield, with variation in the extent of the response. These results represent additional analyses of the same dataset to determine if the degree of response to RPVB on milk, fat and protein yield might be related to the level of production, lactation number, or days in milk (DIM). Results from 50 on-farm switchback trials conducted in 7 countries between 2005 and 2015 were included in the analysis. All herds participated in monthly milk recording services, and all were Holstein herds. A total of 6483 cows, averaging 163 DIM on the first test date, participated in the studies. Data were analyzed using regression models that accounted for the effects of trial, period, days in milk (DIM) and lactation number on milk and component yield. Milk yield and fat yield increased with $\mathrm{B}$ vitamin inclusion, and the extent of change was determined to increase with lactation number $(\mathrm{P}<0.05)$. Protein yield increased with the RPBV and was unaffected by lactation number $(\mathrm{P}<0.05)$ Responses to the RPBV occurred throughout lactation but were found to decline with DIM for milk, fat and protein yield. The global equation revealed that milk yield with the rumen-protected $\mathrm{B}$ vitamin blend $=4.05+[0.917 \times$ control milk $]-$ $[0.0063 \times \mathrm{DIM}]+[0.246 \times$ Lactation number $]\left(\mathrm{R}^{2}=0.798\right)$ The use of regression models allows changes in milk, fat and protein yields with the rumenprotected $\mathrm{B}$ vitamin blend to be more accurately predicted.
\end{abstract}




\section{Keywords}

Meta-Regression, Dairy Nutrition, Rumen Protection, B Vitamins

\section{Introduction}

$B$ vitamins are not routinely provided to lactating dairy cows. The primary reason for this is the ready acceptance of older research showing that the rumen microbes supplied enough of these nutrients to support milk production. With improvements in cow productivity, interest in this area of research has grown in recent times. As a result, microbial B vitamin synthesis is now considered to frequently be suboptimal [1]. The National Research Council [2] acknowledged research that demonstrated potential limitations for biotin, folic acid and pantothenic acid, but concluded that insufficient data were available to support suggesting requirements for these nutrients.

The difficulty in assessing requirements is associated with the fact that rumen microbes do not just produce B vitamins, they also destroy the major portion of $B$ vitamins for feed ingredients ([1] [3] [4] resulting in challenges in assessing response to the inclusion of these nutrients in diets. Improvements have been forthcoming with the use of rumen protection technology, that permits nutrients to escape being exposed to microbial degradation. Through the use of this technology, a rumen-protected B vitamin (RPBV) blend was formulated [5] [6].

This product has been evaluated in numerous on-farm feeding studies. Results from a recent meta-analysis demonstrated that milk, fat and proteins yields were increased by $0.88,0.043$ and $0.033 \mathrm{~kg} /$ cow/day respectively [7]. However, the meta-analysis results also showed that the extent of the responses varied from trial to trial, as did herd demographics, resulting in difficulties in predicting response to the RPBV in advance of feeding. This research was conducted to assess the magnitude of some of the underlying causes of variability involved in response to RPBV allowing results with the use of the product to be predicted and the true value of inclusion to be estimated.

\section{Materials and Methods}

\subsection{Background and Description of Individual Trials}

This research is a continuation of the research published in the accompanying article [7] and the results were generated from the same dataset described in that report. Details of each trial are provided in that report in forest plot format. In brief, results from on-farm trials comparing the commercial product Lactation $V B$ to a control treatment that did not include RPVB (Jefo, St. Hyacinthe, QC Canada) were used. The trials had been conducted in 7 countries between 2005 and 2015 and all been previously analyzed. The RPVB blend provided folic acid, B12, pyridoxine, pantothenic acid, and biotin in a rumen stable lipid matrix, with in-situ rumen stability of $93 \%$ after 24 hours of incubation [5]. The feeding 
rate for the RPVB blend was $3 \mathrm{~g} /$ cow/day.

All trials were monitored by independent consulting nutritionists or veterinarians associated with each farm. The test product was added to the existing diet, which was assumed to be nutritionally adequate, and in no case were the consultants asked to modify the diet. Trials were excluded if there were diet changes during the course of the trial, the RPBV was not added at the correct time, the consultant was unsure of start dates, data were missing or there were changes in the herd monitoring system. Within each trial, cows were deemed eligible for inclusion if they were present and tested in all three periods and were greater than 45 DIM at the first milk test date. All herds were required to subscribe to an independent monthly herd monitoring system equivalent to Dairy Herd Improvement Association.

Protocol requirements included data for each individual cows for lactation number, DIM at the time of milk collection, milk production, milk fat percentage and milk protein percentage for each of the three consecutive periods. Yields of fat and protein were computed on an individual cow basis. Periods were defined as the length of time between individual cow monthly monitoring services and typically ranged from 28 to 33 days. In all cases, trials were analyzed as switchback trials in which the test product was supplied in the center "Test" period (Control-Test Control) with the test compared to the control means by cow.

\subsection{Regression Analysis for Combined Datasets}

Treatment means were compared using a one-way analysis of variance across all lactations, and then for first and later lactation cows separately in order to provide overall means (Minitab LLC, State College, PA, USA). Results were declared significantly different if the $\mathrm{P}$ value was less than 0.05 (i.e., the probability that the differences occurred by chance is under $5 \%$ ).

Regression analyses were used to explore the sources of variation in the responses witnessed based on the meta-analyses [7]. Cows averaged 163, 193 and 222 days in milk on the first, second and third collection. Because data were largely from cows that were past peak in lactation linear regression was applied to assess effects of input variables on the dependent variables analyzed. Data were analyzed using regression models in Minitab 16 (Minitab LLC, State College, PA, USA) to assess the effects of period (control compared to test), DIM on the date of data collection (45 to 428 ) and lactation number, which ranged from 1 to 10 .

\section{Results}

Tables 1-3 provide the global mean values for milk, fat percentage, protein percentage, fat yield and protein yield for all cows (all lactations, Table 1) and then first lactation cows (Table 2) and lastly mature cows (lactation 2 and higher; Table 3). In all cases, the results indicate that milk yield increased, but that the 
Table 1. Means ( \pm SEM) for all cows from all studies with (test) or without (control) the inclusion of rumen protected B vitamins ${ }^{1}$.

\begin{tabular}{cccc}
\hline Parameter & Test & Control & P Level \\
\hline Milk, 1 & $33.12 \pm 0.136$ & $32.22 \pm 0.127$ & $<0.001$ \\
Fat, \% & $3.72 \pm 0.011$ & $3.70 \pm 0.010$ & $=0.236$ \\
Protein, \% & $3.23 \pm 0.005$ & $3.22 \pm 0.05$ & $<0.551$ \\
Fat yield, kg & $1.22 \pm 0.006$ & $1.17 \pm 0.005$ & $<0.001$ \\
Protein yield, kg & $1.05 \pm 0.004$ & $1.02 \pm 0.004$ & $<0.001$ \\
\hline
\end{tabular}

${ }^{1}$ Data reflect results from 6483 cows that averaged 163 days in milk at the first milk test date, with an average lactation of 2.20 .

Table 2. Means ( \pm SEM) for all first lactation cows from all studies with (test) or without (control) the inclusion of rumen-protected B vitamins ${ }^{1}$.

\begin{tabular}{cccc}
\hline Parameter & Test & Control & P Level \\
\hline Milk, 1 & $30.18 \pm 0.183$ & $29.47 \pm 0.174$ & $=0.005$ \\
Fat, \% & $3.62 \pm 0.018$ & $3.62 \pm 0.017$ & $=0.891$ \\
Protein, \% & $3.23 \pm 0.009$ & $3.21 \pm 0.008$ & $=0.101$ \\
Fat yield, kg & $1.08 \pm 0.007$ & $1.04 \pm 0.006$ & $<0.001$ \\
Protein yield, kg & $0.97 \pm 0.005$ & $0.93 \pm 0.005$ & $<0.001$ \\
\hline
\end{tabular}

${ }^{1}$ Data reflect results from 1815 first lactation cows that averaged 169 days in milk at the first test date.

Table 3. Means ( \pm SEM) for all mature cows from all studies with (test) or without (control) the inclusion of rumen-protected B vitamins ${ }^{1}$.

\begin{tabular}{cccc}
\hline Parameter & Test & Control & P Level \\
\hline Milk, 1 & $34.27 \pm 0.174$ & $33.29 \pm 0.160$ & $<0.001$ \\
Fat, \% & $3.76 \pm 0.014$ & $3.74 \pm 0.012$ & $=0.206$ \\
Protein, \% & $3.23 \pm 0.006$ & $3.23 \pm 0.006$ & $=0.835$ \\
Fat yield, kg & $1.27 \pm 0.007$ & $1.23 \pm 0.007$ & $<0.001$ \\
Protein yield, kg & $1.08 \pm 0.005$ & $1.05 \pm 0.004$ & $<0.001$ \\
\hline
\end{tabular}

${ }^{1}$ Data reflect results from 4668 mature cows that averaged 160 days in milk at the first test date, with an average lactation of 2.67 .

composition of the milk (percent of components), on average, did not change. This indicates that the increase in milk yield did not result in the dilution of components, but rather than components remained consistent as milk production increased. Increases in milk yield were greater for mature cows than for cows in their first lactation. This may be associated with the diversion of nutrients to growth for the first lactation cows.

These results are somewhat different than from data reported previously where the same product was tested [6]. In that study, 12 trials were all conducted in Canada or USA. There was a wider range in milk yield results in the current study and may reflect a greater geographic range from which data were col- 
lected. The current analysis involved results from 7 countries (Australia-5, Brazil-4, Canada, 24, Chile-2, Colombia-1, Mexico-1, and USA-13 trials), with a range in mean milk production of the herds from 24 to $47 \mathrm{~kg}$. With this range came greater variability as is indicated by the standard error values in Tables 1-3. The advantage of developing regression models from these data is to further identify the likely responses based upon current herd dynamics.

\subsection{Milk Yield}

The regression models shown in Table 4 demonstrate that there are differences in milk yield that could be associated with control milk yield. The slope value was lower for first lactation cows than for mature cows. The equations suggest that the improvement in milk production obtained through the inclusion of the $\mathrm{RPBV}$ in the diet may be of greater importance for cows at reduced levels of production, particularly for the first lactation cows.

The feeding trials included in these analyses were conducted with cows past peak in their lactation cycle and to date there have been no routine studies available for cows in the early part of their lactation cycle. Therefore, the models shown in Table 4 may or may not accurately represent the same changes in milk that might occur in early lactation. Cows in early lactation often have compromised intakes and may be suffering greater imbalances in B vitamins than mid-lactation cows.

In an effort to determine the effects of stage of lactation within the parameters of the data collected, the effects of DIM on milk yield were determined (Table 5). After peak lactation, milk yield declines with DIM. The rate of change in milk yield with DIM is less for first lactation cows than for mature cows when the diets did and did not include the rumen-protected B vitamin blend. The slope values were similar for both treatment groups of cows and do not suggest that there were changes in milk persistency when cows received the added B vitamins. However, the actual magnitude of improvement diminished with advancing lactation, as is illustrated for all cows in Figure 1. These results indicate that the stage of lactation, as defined by DIM is a source of variation and that a greater response to the rumen-protected $\mathrm{B}$ vitamin blend might be anticipated for cows in early lactation.

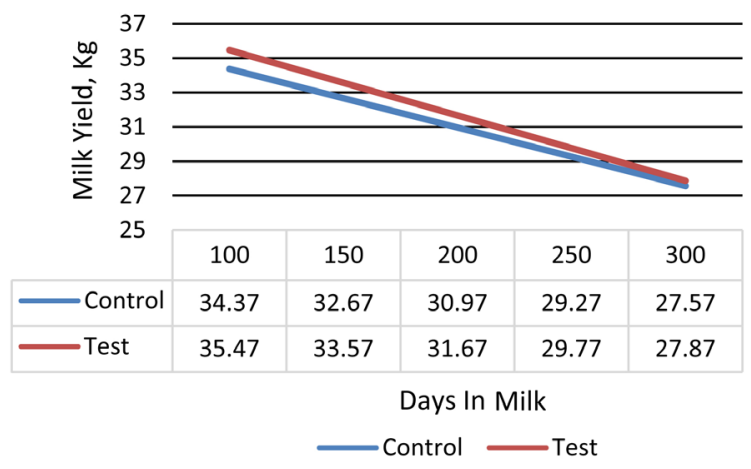

Figure 1. Regression of days in milk on milk yield for all cows. 
Table 4. Effects of control milk yield on milk yield with the dietary inclusion of rumenprotected B vitamins.

\begin{tabular}{ccccc}
\hline Group & Intercept & Slope & $\mathbf{R}^{2}$ & P Level \\
\hline All cows & 2.54 & 0.949 & 0.793 & $<0.001$ \\
First lactation & 3.83 & 0.890 & 0.721 & $<0.001$ \\
Mature cows & 2.52 & 0.953 & 0.798 & $<0.001$ \\
\hline
\end{tabular}

Table 5. Effect of days in milk on milk yield, with and without the dietary inclusion of rumen-protected B vitamins.

\begin{tabular}{|c|c|c|c|c|}
\hline Group & Intercept & Slope & $\mathbf{R}^{2}$ & P Level \\
\hline & \multicolumn{4}{|c|}{ Control } \\
\hline All cows & 37.77 & -0.034 & 0.143 & $<0.001$ \\
\hline First lactation & 32.18 & -0.016 & 0.068 & $<0.001$ \\
\hline \multirow[t]{2}{*}{ Mature cows } & 39.97 & -0.042 & 0.177 & $<0.001$ \\
\hline & \multicolumn{4}{|c|}{ Test } \\
\hline All cows & 39.27 & -0.038 & 0.154 & $<0.001$ \\
\hline First lactation & 33.02 & -0.017 & 0.069 & $<0.001$ \\
\hline Mature cows & 41.74 & -0.047 & 0.195 & $<0.001$ \\
\hline
\end{tabular}

The effects of control milk production and DIM were combined in the next regression model (Table 6). The negative slope with DIM further indicates that late lactation cows may be slightly less responsive at any level of production.

Milk yield response to the rumen-protected $\mathrm{B}$ vitamin blend was also found to increase with lactation number $(\mathrm{P}<0.001)$, increasing by $0.075 \mathrm{~kg} /$ year of lactation. All independent variables tested in the model for milk yield were highly significant $(P<0.001)$. Equation $(1)$ generated is given below and should account for much of the between trial variability:

$$
\begin{aligned}
& \text { Milk yield with RPBV } \\
& =4.05+[0.917 * \text { control milk }]-[0.0063 * \mathrm{DIM}] \\
& +[0.246 * \text { Lactation number }], \mathrm{R}^{2}=0.798
\end{aligned}
$$

\subsection{Milk Fat Yield}

As Table 1 indicated, yield of milk fat was increased overall when the RPBV was added to the diet. The regression equations for expected fat yield on control (existing) fat yield are provided in Table 7 . The relationship between yield with the RPBV and existing yield as indicated by the $\mathrm{R}^{2}$ value is high. With the slope values below unity, the models generated in Table 7 suggest that fat yields will increase to a greater extent when control fat yields are low. The results suggest that the RPBV may contribute to alleviating a deficiency that causes impairment in lipid synthesis.

Similar to findings with milk yield, DIM was determined to impact milk fat yield (Table 8). However, the rate of change in fat yield (slope value) was lower 
Table 6. Effects of control milk and days in milk on response to the dietary inclusion of rumen protected B vitamins.

\begin{tabular}{ccccccc}
\hline Group & Intercept & Slope yield & P Level & Slope DIM & P Level & $\mathbf{R}^{2}$ \\
\hline All cows & 4.047 & 0.923 & $<0.001$ & -0.0063 & $<0.001$ & 0.797 \\
First lactation & 4.616 & 0.882 & $<0.001$ & -0.0026 & $<0.001$ & 0.723 \\
Mature cows & 5.042 & 0.918 & $<0.001$ & -0.0083 & $<0.001$ & 0.803 \\
\hline
\end{tabular}

Table 7. Effects of control milk fat yield on milk fat yield with the dietary inclusion of rumen-protected B vitamins.

\begin{tabular}{ccccc}
\hline Group & Intercept & Slope & $\mathbf{R}^{2}$ & P Level \\
\hline All cows & 0.253 & 0.818 & 0.587 & $<0.001$ \\
First lactation & 0.288 & 0.756 & 0.489 & $<0.001$ \\
Mature cows & 0.270 & 0.814 & 0.582 & $<0.001$ \\
\hline
\end{tabular}

Table 8. Effect of days in milk in milk fat yield with and without the dietary inclusion of rumen-protected $\mathrm{B}$ vitamins.

\begin{tabular}{ccccc}
\hline Group & Intercept & Slope & $\mathbf{R}^{2}$ & P Level \\
\hline All cows & 1.35 & Control & \\
First lactation & 1.10 & -0.0011 & 0.086 & $<0.001$ \\
Mature cows & 1.45 & -0.0003 & 0.022 & $<0.001$ \\
& & -0.0014 & 0.116 & $<0.001$ \\
All cows & 1.42 & Test & & $<0.001$ \\
First lactation & 1.04 & -0.0012 & 0.099 & $<0.001$ \\
Mature cows & 1.57 & -0.0004 & 0.028 & $<0.001$ \\
\hline
\end{tabular}

for cows in their first lactation than cows in later lactations for both the control and test feeding periods. Thus, herd demographics (first lactation to mature cow ratio) can come into play when comparing herds and predicting responses. The intercept values were higher for the test group of all cows, which somewhat reflects the greater overall yield found for this study (Figure 2).

Table 9 provides results when both control fat yield and DIM were included in the regression model. The results indicated that the likelihood of a response to the RPBV declines with DIM. This might be related to greater intakes later in lactation.

As with milk yield, milk fat yield was positively influenced by lactation number and increased by $0.045 \mathrm{~kg} /$ day for each lactation with the inclusion of RPBV. With control level of milk production, DIM and lactation number all impacting the improvement in fat yield obtained with the RPBV product, the global Equations $(2,3)$ generated were:

$$
\begin{aligned}
& \text { Milk fat yield with RPBV } \\
& \begin{aligned}
= & 0.199+0.0304 * \text { control milk }-0.0006 * \mathrm{DIM} \\
& +0.055 * \text { Lactation number, } \mathrm{R}^{2}=0.571
\end{aligned}
\end{aligned}
$$




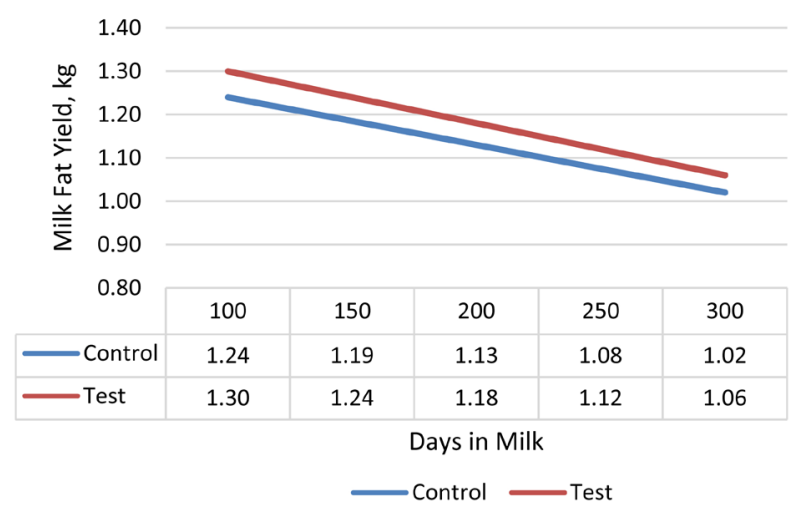

Figure 2. Regression of days in milk on milk fat yield for all cows.

Table 9. Effects of control milk fat yield and days in milk on response to the dietary inclusion of rumen-protected B vitamins.

\begin{tabular}{ccccccc}
\hline Group & Intercept & Slope yield & P Level & Slope DIM & P Level & $\mathbf{R}^{2}$ \\
\hline All cows & 0.351 & 0.788 & $<0.001$ & -0.0004 & $<0.001$ & 0.596 \\
First lactation & 0.326 & 0.752 & $<0.001$ & -0.00015 & $<0.001$ & 0.496 \\
Mature cows & 0.402 & 0.772 & $<0.001$ & -0.0005 & $<0.001$ & 0.594 \\
\hline
\end{tabular}

Milk fat yield with RPBV

$$
\begin{aligned}
= & -1.181+0.0362 * \text { control milk }+0.322 * \text { control milk fat percentage } \\
& -0.000075 * \text { DIM }+0.0353 * \text { Lactation number, } \mathrm{R}^{2}=0.951
\end{aligned}
$$

\subsection{Milk Protein Yield}

Results from the same series of models are provided for milk protein yield. Table 10 shows how that the inclusion of the RPBV modified milk protein yield in all cows. The slope for change in milk protein yield was slightly less steep for the first lactation cows than for the mature cows.

Below, Table 11 provides the prediction equations for the effects of DIM on yield of milk protein. The intercepts were greater for the test cows in all age categories, but as Figure 3 graphically demonstrates, these differences narrow with DIM (Table 12).

Milk protein yield with the inclusion of the RPBV can be predicted from the yield of protein without the use of the rumen-protected B vitamin blend, and DIM. While differences were found between first lactation cows and all cows of lactation greater than one, lactation number could not be used to describe change in milk protein yield, providing an $\mathrm{R}^{2}$ value of only 0.0211 . As a result, lactation number could not be included in a global Equation (4):

$$
\begin{aligned}
& \text { Milk protein yield with RPBV } \\
& \begin{aligned}
= & -0.958+0.0307 * \text { control milk yield } \\
& +0.312 * \text { control milk protein percentage } \\
& -0.000067 * \mathrm{DIM}, \mathrm{R}^{2}=0.961
\end{aligned}
\end{aligned}
$$




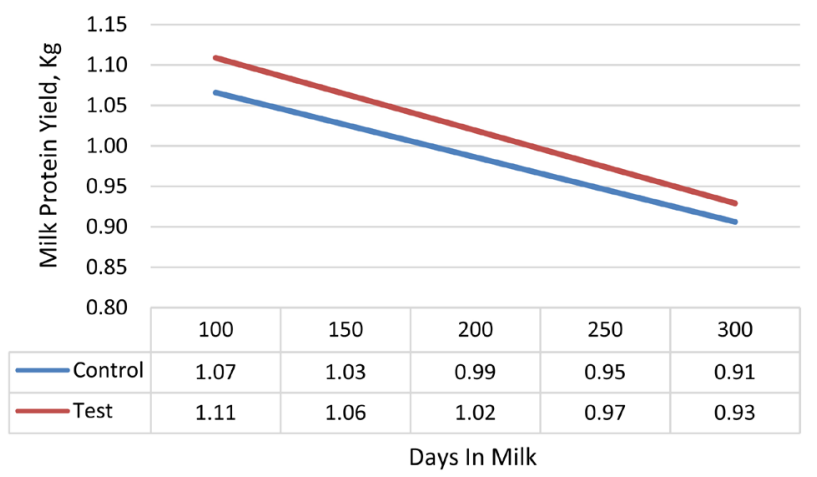

Figure 3. Regression of days in milk on milk protein yield for all cows.

Table 10. Effects of control milk protein yield on milk on response to the dietary inclusion of rumen-protected B vitamins.

\begin{tabular}{ccccc}
\hline Group & Intercept & Slope & $\mathbf{R}^{2}$ & P Level \\
\hline All cows & 0.133 & 0.933 & 0.683 & $<0.001$ \\
First lactation & 0.167 & 0.858 & 0.635 & $<0.001$ \\
Mature cows & 0.131 & 0.908 & 0.688 & $<0.001$ \\
\hline
\end{tabular}

Table 11. Effect of days in milk on change in milk protein yield with and without rumenprotected B vitamin blend.

\begin{tabular}{|c|c|c|c|c|}
\hline Group & Intercept & Slope & $\mathbf{R}^{2}$ & P Level \\
\hline & \multicolumn{4}{|c|}{ Control } \\
\hline All cows & 1.146 & -0.0008 & 0.096 & $<0.001$ \\
\hline First lactation & 0.968 & -0.0002 & 0.149 & $<0.001$ \\
\hline \multirow[t]{2}{*}{ Mature cows } & 1.122 & -0.0010 & 0.139 & $<0.001$ \\
\hline & \multicolumn{4}{|c|}{ Test } \\
\hline All cows & 1.199 & -0.0009 & 0.105 & $<0.001$ \\
\hline First lactation & 1.001 & -00024 & 0.069 & $<0.001$ \\
\hline Mature cows & 1.273 & -0.0010 & 0.149 & $<0.001$ \\
\hline
\end{tabular}

Table 12. Effects of control milk protein yield and days in milk on response to rumenprotected B vitamin blend.

\begin{tabular}{ccccccc}
\hline Group & Intercept & Slope yield & P Level & Slope DIM & P Level & $\mathbf{R}^{2}$ \\
\hline All cows & 0.351 & 0.788 & $<0.001$ & -0.0004 & $<0.001$ & 0.596 \\
First lactation & 0.326 & 0.752 & $<0.001$ & -0.00015 & $<0.001$ & 0.496 \\
Mature cows & 0.402 & 0.772 & $<0.001$ & -0.0005 & $<0.001$ & 0.594 \\
\hline
\end{tabular}

\section{Discussion}

Results from a meta-analysis that incorporated these same trials [7] clearly indicated that dairy cows around the world, reared with varying feed systems respond to the inclusion of RPBV with improved milk, fat and protein yields av- 
eraging $0.88,0.04$ and $0.03 \mathrm{~kg} / \mathrm{cow} /$ day respectively. By necessity, better managed herds, with the capability to capture accurate results were selected to comply with the complexities of handling such trials. As such, one would anticipate that these herds would be given well formulated diets with few if any nutrients that might be deficient.

The meta-analysis [7] showed there were sources of variability from trial to trial, and assuming that the weighted average changes could be applied to other herds might be inaccurate. While there were logically uncontrolled environmental factors that would have influenced results on a trial-by-trial basis, the models clearly identified herd demographic factors that influenced the findings.

The models generated herein demonstrated that first lactation cows producing more than $20 \mathrm{~kg}$ of milk per day in general exhibit a lower response to the inclusion of the RPBV than cows from lactation two and above. Because the percentage of first lactation cows varied with trial, this factor can account for some of the variability noted. Insufficient supply of B vitamins would not be expected at lesser amounts of milk production. However, these results clearly show that cows that are producing average or below level of milk are targets for dietary inclusion of RPBV. This is however, modified by DIM, with late lactation cows being less responsive than those in mid lactation.

Furthermore, the overall effects are associated with all of the B vitamins included in the RPBV and do not pertain to a particular vitamin. Girard et al. [8] determined that weekly injections of folic acid did not alter milk production in early lactation, but increased milk yield in late lactation due to the need for that vitamin to support fetal development. Ferreira et al. [10] found that biotin improved milk production in high producing but not in low producing cows.

Two factors missing from all these feeding studies are data regarding feed intake and results from cows in early lactation. Higher feed intake has been demonstrated to increase the yield of rumen microbes [11] [12], the major source of $B$ vitamins as unprotected feed sources is largely degraded in the rumen [3]. Indeed, heat stress, a factor known to reduce feed intake, was shown to reduce milk production more severely in the absence of RPBV [12]. In the higher producing cows, it is possible that greater feed intake improved the availability of $\mathrm{B}$ vitamins from ruminal supply. This would not be true, however, in high producing cows in early lactation, which would be expected to have lower intakes. Studies are needed to assess responses to RPBV in early lactation and with known intakes in order to improve these response models.

\section{Conclusion}

This research revealed that lactating dairy cows respond to the addition of $\mathrm{B}$ vitamins when they are provided in a rumen-protected form. The inclusion of RPVB in diets for lactating cows increased milk yield, fat yield and protein yield. The extent of response can be predicted from variables readily available on farms and include milk production, DIM and lactation number. 


\section{Acknowledgements}

The authors are indebted to the farm owners for allowing these tests to be conducted, and to the nutritionists and veterinarians who carried out the trials.

\section{Conflicts of Interest}

There are no conflicts of interest with respect to this study.

\section{References}

[1] Girard, C.L. and Graulet, B. (2021) Methods and Approaches to Estimate B Vitamin Status in Dairy Cow: Knowledge Gaps and Advances. Methods, 186, 52-58. https://doi.org/10.1016/j.ymeth.2020.05.021

[2] National Research Council (NRC) (2001) Nutrient Requirements of Dairy Cattle. Seventh Revised Edition, National Academy Press, Washington DC, USA.

[3] Santschi, D.E., Berthiaume, R., Matte, J.J., Mustafa, A.F. and Girard, C.L. (2005) Fate of Supplementary B-Vitamins in the Gastrointestinal Tract of Dairy Cows. Journal of Dairy Science, 88, 2043-2054. https://doi.org/10.3168/jds.S0022-0302(05)72881-2

[4] Ragaller, V., Lebzien, P., Bigalke, W., Südekum, K.H., Hüther, L. and Flachowsky, G. (2011) Effects of a Pantothenic Acid Supplementation to Different Rations on Ruminal Fermentation, Nutrient Flow at the Duodenum, and on Blood and Milk Variables of Dairy Cows. Journal of Animal Physiology and Animal Nutrition, 95, 730-743. https://doi.org/10.1111/j.1439-0396.2010.01103.x

[5] Sacadura, F.C., Robinson, P.H., Evans, E. and Lordelo, M. (2008) Effects of a Ruminally Protected B-Vitamin Supplement on Milk Yield and Composition of Lactating Dairy Cows. Animal Feed Science and Technology, 144, 111-124. https://doi.org/10.1016/j.anifeedsci.2007.10.005

[6] Evans, E. and Mair, D.T. (2013) Effects of a Rumen Protected B Vitamin Blend upon Milk Production and Component Yield in Lactating Dairy Cows. Open Journal of Animal Sciences, 3, 76-82. https://doi.org/10.4236/ojas.2013.31011

[7] Evans, E., Leclerc, H., AlZahal, O. and Santin, E. (2021) Assessment of Lactational Performance in Dairy Cows Receiving a Rumen Protected B Vitamin Blend during Lactation: Part 1: Meta-Analysis of 50 Studies. Open Journal of Animal Sciences, 11, 580-590. https://doi.org/10.4236/ojas.2021.114039

[8] Girard, C.L., Matte, J.J. and Tremblay, G.F. (1995) Gestation and Lactation of Dairy Cows: A Role for Folic Acid? Journal of Dairy Science, 78, 404-411. https://doi.org/10.3168/jds.S0022-0302(95)76649-8

[9] Ferreira, G., Weiss, W.P. and Willet, L.B. (2007) Changes in Measures of Biotin Status Do not Reflect Milk Yield Responses When Dairy Cows Are Fed Supplemental Biotin. Journal of Dairy Science, 90, 1452-1459. https://doi.org/10.3168/jds.S0022-0302(07)71630-2

[10] Noel, S.J., Olijhoek, D.W., Mclean, F., Løvendahl, P., Lund, P. and Højberg, O. (2019) Rumen and Fecal Microbial Community Structure of Holstein and Jersey Dairy Cows as Affected by Breed, Diet, and Residual Feed Intake. Animals, 9, Artilce No. 498. https://doi.org/10.3390/ani9080498

[11] Wassie, S.E., Ali, A.I.M., Korir, D., Butterbach-Bahl, K., Goopy, J., Merbold, L., Schlecht, E. and Dickhoefer, U. (2019) Effects of Feed Intake Level on Efficiency of Microbial Protein Synthesis and Nitrogen Balance in Boran Steers Consuming 
Tropical Poor-Quality Forage. Archives of Animal Nutrition, 73, 140-157.

https://doi.org/10.1080/1745039X.2019.1572343

[12] Gressley, T.F., Shivas, I.C. and Leclerc, H. (2018) Milk and Components Response of Dairy Cows When Supplemented with a Rumen Protected B Vitamins Blend during Heat Stress. Journal of Dairy Science, 101, Article No. 306. 